\title{
Diversifikasi Inovatif Olahan Jagung Sebagai Penyokong Perekonomian Masyarakat Desa Tagungguh
}

\author{
Masduki \\ Program Studi Sastra Inggris Fakultas Ilmu Sosial dan Ilmu Budaya \\ Universitas Trunojoyo Madura \\ E-mail : masduki@trunojoyo.ac.id \\ DOI: http://dx.doi.org/10.21107/pgd.v5i1
}

\begin{abstract}
Abstrak
Artikel Diterima : 12 November 2018/ Revisi : 7 Februari 2019/Terbit : 15 April 2019

Hasil pertanian jagung belum dimaksimalkan pemanfaatannya oleh masyarakat. Jagung yang dijual seringkali dihargai dengan sangat murah dan salah satu sebab adalah jagung dijual dalam bentuk bahan baku. Selain itu, jagung hanya dimanfaatkan untuk pakan ternak dan selebihnya dikonsumsi sendiri tanpa adanya pengolahan lebih lanjut. Tujuan dari artikel ini adalah mendeskripsikan kegiatan diversifikasi komoditas jagung mulai pada tahap pengolahan sampai cara memasarkan hasil pengolahan jagung. Pelaksanaan kegiatan ini dilaksanakan pada bulan Desember 2018 hingga Januari 2019 melalui kegiatan KKN mahasiswa Universitas Trunojoyo Madura. Lokasi kegiatan berada di Desa Tagungguh Kecamatan Tanjung Bumi Kabupaten Bangkalan. Secara umum kegiatan ini dilaksanakan secara simultan yaitu pengelolaan puding jagung sedot (PJS), pengelolaan bubur jagung (Burung), pembuatan kerajinan dari biji jagung, dan pemasaran produk. Kegiatan diversifikasi olahan komoditas jagung ini memaksimalkan hasil pertanian jagung yang merupakan salah satu komoditas yang unggul di desa Tagungguh dan diharapkan dapat meningkatkan perekonomian masyarakat sekitar. Kegiatan tersebut mendapatkan tanggapan yang cukup positif dari masyarakat dan pemangku kepentingan dan selanjutnya bisa diberikan tindak lanjut.
\end{abstract}

Kata Kunci : diversifikasi, jagung, pengolahan, inovatif, pemasaran

\section{PENDAHULUAN}

Hasil pertanian yang melimpah di pedesaan seringkali menjadi permasalahan tersendiri bagi masyarakat terutama dalam meningkatkan potensi hasil pertanian tersebut yang mampu menjadi penyokong bahkan tulang punggung kehidupan masyarakat (Rahayuningsih, 2016). Kondisi pertanian di pedesaan terindikasi suatu permasalahan seperti kurang nya pemahaman masyarakat petani untuk lebih memikirkan masalah pertanian berkelanjutan dalam jangka panjang (long term sustainability). Upaya awal yang dapat dilakukan untuk pengoptimalisasian hasil pertanian (Efendy, 2012) yakni dengan melakukan beberapa terobosan sehingga produk yang dihasilkan dari potensi tersebut memiliki nilai tambah serta nilai jual yang lebih tinggi dari sebelumnya dengan salah satu cara adalah dengan mengedukasi masyarakat untuk memanfaatkan setiap hasil pertanian yang melimpah yang bukan hanya dijual dalam kondisi mentah (bahan baku) melainkan menjadi sebuah produk inovatif yang kreatif sebagai salah satu sarana memajukan perekonomian masyarakat. Dengan adanya produk yang dihasilkan dari potensi tersebut diharapkan dapat meningkatkan perekonomian dan sekaligus menambah lapangan pekerjaan baru bagi masyarakat.

Berdasarkan data BPS Jawa Timur tahun 2015, jumlah penduduk di Madura pada tahun 2014 sebanyak 2.731 .633 orang dengan luas wilayah lebih dari $5300 \mathrm{~km}^{2}$ (Rahayuningsih, 2016). Kabupaten Bangkalan merupakan kabupaten dengan total populasi sebanyak 1.190.129 jiwa, dengan luas wilayah sekitar $1.001 \mathrm{~km}^{2}$.Tanjung Bumi salah satu dari 18 kecamatan yang ada di Bangkalan. Desa Tagungguh terletak sejauh $42,3 \mathrm{~km}$ dari kota Bangkalan dan $5 \mathrm{~km}$ dari Kecamatan Tanjung Bumi. Desa Tagungguh berada di kawasan pantai utara pulau Madura yang memiliki luas wilayah 497.273,65 Ha, dengan dibatasi oleh wilayah desa-desa lainnya yakni seperti Desa Tlangoh sebelah utara, Desa Dupok sebelah selatan, Desa Plangiran sebelah barat dan Desa Bandang Dajah sebelah timur.

Penduduk Desa Tagungguh berjumlah 5.152 jiwa yang tersebar ke dalam 8 dusun, diantaranya yaitu: Dusun Larangan, Dusun Tengginah, Dusun Larangan Barat, Dusun Pacenan, Dusun Sodin, Dusun Guwah, Dusun Rojing, Dusun Paceleng. Jumlah penduduk di Desa Tagungguh menurut jenis kelamin dan sex ratio yaitu, laki- 
laki sebanyak 2.494 jiwa dan perempuan sebanyak 2.658 jiwa Jumlah kepala keluarga yang terdapat di Desa Tagungguh sebanyak 1.589 .

Salah satu hasil pertanian yang melimpah di Desa Tagungguh adalah jagung. Namun demikian, hasil pertanian jagung tersebut masih belum dimaksimalkan pemanfaatannya, dan masyarakat lebih cenderung untuk langsung menjual jagung tersebut untuk memenuhi kehidupannya. Jagung yang dijual seringkali dihargai dengan sangat murah, hal ini karena salah satu sebab adalah jagung dijual tanpa pengolahan (Amzeri, 2016). Selain itu, hasil panen berupa jagung tersebut hanya dimanfaatkan untuk pakan ternak dan selebihnya dikonsumsi sendiri tanpa adanya pengolahan lebih lanjut. Sementara itu, disisi lain jagung dapat dimanfaatkan menjadi berbagai macam aneka olahan pangan dan kerajinan tangan yang bernilai jual tinggi dan sebagai peluang usaha baru sebagai industri rumah tangga.

Solusi yang efektif yang dapat diterapkan dari fenomema tersebut adalah adanya kegiatan hilirisasi komoditas jagung mulai pada tahap pengolahan sampai cara memasarkan hasil pengolahan jagung tersebut. Lebih lanjut, tujuan dari artikel ini adalah untuk memberikan gambaran mengenai bagaimana cara meningkatakan komoditas jagung sebagai penyokong perekonomian masyarakat melalui pengolahan jagung yang inovatif dan berdaya saing.

\section{METODE}

Kegiatan diversifikasi olahan komoditas jagung ini dilaksanakan melalui program Kuliah Kerja Nyata (KKN) mahasiswa Universitas Trunojoyo Madura yang berlangsung pada bulan Desember 2018 hingga Januari 2019. Pelaksanaan kegiatan diversifikasi komoditas jagung dengan pengelolaan inovatif ini pada dasarnya adalah pembuatan beberapa produk olahan jagung diantaranya adalah: (1) Puding Jagung Sedot (PJS); (2) Bubur Jagung Tagungguh (Burung Tagungguh); (3) Pembuatan Kerajinan dari Biji Jagung dan (4) Pemasaran produk. Tahapan kegiatan ini adalah :

1. Menyiapkan lokasi kegiatan, dapat berupa balai desa, lapangan, atau gedung milik desa.

2. Mengundang Ibu-Ibu PKK sebagai sasaran utama kegiatan melalui undangan langsung atau tertulis.

3. Menyiapkan alat dan bahan kegiatan sekaligus dekorasi tempat kegiatan.
4. Mempresentasikan dan mempraktekkan secara langsung metode pengolahan, pengemasan, dan pemasaran produk.

5. Melakukan kerjasama dengan kelompok PKK, karang taruna untuk merealisasikan program sekaligus melakukan pengawasan mulai dari pengadaan bahan baku, produksi, pengemasan, penyimpanan, hingga pemasaran ke konsumen.

\section{HASIL DAN PEMBAHASAN \\ Kondisi Umum Lokasi}

Desa Tagungguh sebenarnya merupakan sebuah desa yang masih dalam tahap berkembang. Masyarakat di Desa Tagungguh dalam bidang ekonomi pun tergolong menengah ke bawah, dengan mayoritas masyarakatnya memiliki profesi sebagai petani jagung dan singkong. Dengan lokasi desa yang memiliki lahan persawahan dan perkebunan desa Tagungguh memiliki hasil pertanian yang cukup melimpah seperti komoditas jagung dan singkong yang belum dikembangkan. Kurangnya Pemahaman masyarakat akan pentingnya pendidikan disinyalir merupakan akar penyebab desa ini tidak mengalami kemajuan yang signifikan. Adanya potensi hasil pertanian yang kurang dioptimalkan pengelolaannya di Desa Tagungguh, kurangnya wawasan dan keterampilan merupakan kendala utama hal ini terjadi. Sehingga dibutuhkan upaya-upaya untuk menyelesaikan kendala tersebut, tentunya melalui pendidikan dan teknologi.

Jumlah dusun di Desa Tagungguh sebanyak 8 dusun. Jumlah sekolah di Desa Tagungguh sebanyak 3 Sekolah Dasar (SD) Negeri dan 1 Sekolah Menengah Pertama (SMP). Data tersebut secara umum menggambarkan salah satu kondisi pendidikan di Kabupaten Bangkalan yang terdiri dari pendidikan umum yang meliputi Sekolah Dasar (SD), Sekolah Menengah Pertama (SMP), Sekolah Menengah Atas (SMA), dan Sekolah Menengah Kejuruan (SMK) (Saputro, 2016). Desa Tagungguh memiliki sarana dan prasarana desa, yaitu 1 Balai Desa, 9 Masjid, 11 Km jalan Kabupaten, 0 Km jalan Kecamatan, 24 $\mathrm{Km}$ jalan Desa. Desa Tagungguh merupakan desa yang kaya akan sumber daya alam yang melimpah juga di dukung oleh masyarakat yang sebagian besar berprofesi sebagai petani. Masih banyak sekali sumber daya alam desa Tagungguh yang belum dimanfaatkan oleh masyarakat secara maksimal, apabila hal tersebut dapat dikelola secara seksama dapat memberikan banyak manfaat bagi masyarakat desa 
Tagungguh sendiri. Berbagai sumber daya alam tersebut antara lain: jagung, singkong, padi, rambutan, dan pisang. Kegiatan sosial ekonomi masyarakat Desa Tagungguh merupakan pendukung utama terhadap perkembangan perekonomian masyarakat. Adapun sarana dan prasarana pendukung kegiatan ekonomi yang ada diantaranya: Koperasi, Program Perbandingan Pengembangan Ekonomi Lokal (PeEL), Unit Pengelolaan Keuangan (UPK), maupun Gabungan Kelompok Tani (Gapoktan).

\section{Pelaksanaan Kegiatan}

Pelaksanaan kegiatan hilirisasi komoditas jagung dengan pengelolaan inovatif ini adalah selama 1 (satu) bulan mulai tanggal 24 Desember 2018 sampai 25 Januari 2019 di Desa Tagungguh. Adapun kegiatan tersebut dilaksanakan secara simultan yaitu Pengelolaan Puding Jagung Sedot (PJS), Pengelolaan Bubur Jagung (Burung), Pembuatan Kerajinan dari Biji Jagung, dan Pemasaran produk PJS dan Burung.

\section{Pembuatan Pengelolaan Puding Jagung Sedot $\underline{(P J S)}$}

Tujuan dari kegiatan ini adalah memberikan pelatihan kepada masyarakat tentang pengolahan jagung menjadi puding jagung sedot. Manfaat dari kegiatan ini adalah dapat meningkatkan nilai tambah jagung, ketika jagung melimpah dan harga produk rendah. Jagung dapat di olah menjadi berbagai olahan yang mudah. Sehingga masyarakat dapat membuka peluang usaha sebagai indutri rumah tangga. Sasaran kegitan ini ditujukan untuk Ibu-ibu PKK desa Tagungguh sehingga dapat memiliki kegiatan baru yang sesuai dan dapat menambah penghasilan. Alat dan bahan yang digunakan untuk pembuatan Puding Jagung Sedot (PJS) adalah menggunakan alat: kompor, panci, wadah, saringan, sendok sayur, plastik/botol, sedotan, sedangkan bahan yang disiapkan adalah: susu kental manis, jagung, agar-agar, gula pasir, pewarna makanan, air, dan maizena. Kegiatan pengolahan Puding Jagung Sedot ini memaksimalkan hasil pertanian jagung yang merupakan salah satu komoditas yang unggul di Desa Tagungguh. Saat ini hasil panen berupa jagung hanya dimanfaatkan untuk pakan ternak dan selebihnya dikonsumsi sendiri tidak ada pengolahan lebih lanjut setelah adanya pemanenan. Sedangkan disisi lain jagung dapat dimanfaatkan menjadi banyak aneka olahan pangan yang dapat menambah perekonomian warga Desa Tagungguh. Oleh karena itu dengan adanya kegiatan pembuatan Puding Jagung Sedot
(PJS) diharapkan dapat diterapkan oleh masyarakat sehingga dapat meningkatkan perekonomian jiwa kewirausahaan (Casson, 2012).

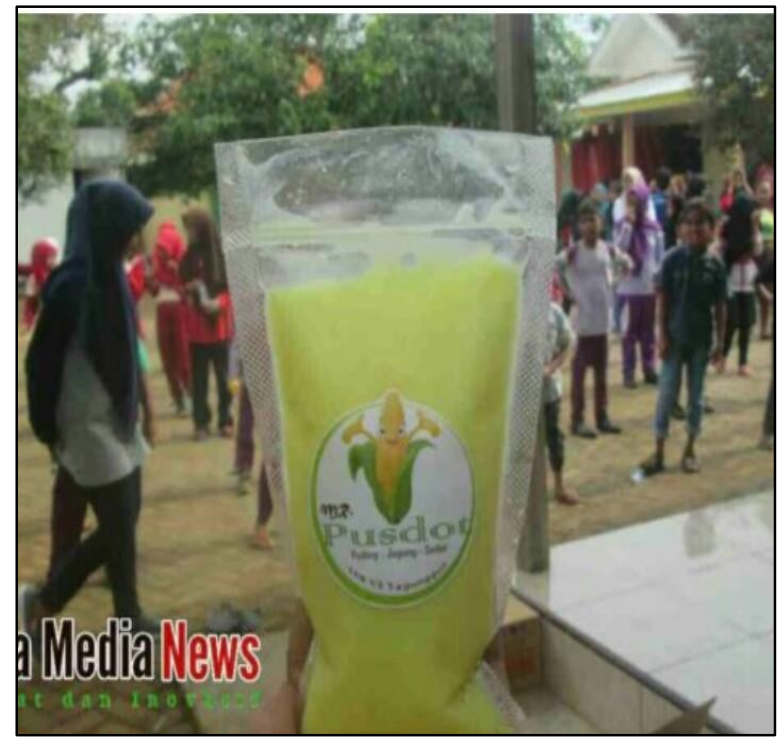

Gambar 1. Kemasan Puding Jagung Sedot (PJS)

\section{Pengolahan Bubur Jagung Tagungguh (Burung Tagungguh)}

Tujuan dari kegiatan ini adalah memberikan pelatihan kepada masyarakat tentang pengolahan jagung menjadi bubur jagung. Adapun manfaat nya adalah dapat meningkatkan nilai tambah jagung, ketika jagung melimpah dan harga produk rendah. Jagung dapat di olah menjadi berbagai olahan yang mudah sehingga masyarakat dapat membuka peluang usaha sebagai indutri rumah tangga. Sasaran dari kegiatan ini adalah Ibu-ibu PKK Desa Tagungguh. Alat yang digunakan di dalam pembuatan Bubur Jagung Tagungguh ini adalah: alat serut, kompor, panic, sendok, sedangkan bahan-bahan yang digunakan adalah: jagung, santan kental, gula pasir, garam, vanilla bubuk, daun pandan, kelapa muda, dan tepung terigu.

Jagung merupakan salah satu komoditas yang unggul di desa Tagungguh Kecamatan Tanjung Bumi Kabupaten Bangkalan. Saat ini hasil panen berupa Jagung hanya dimanfaatkan untuk pakan ternak dan selebihnya dikonsumsi sendiri tidak ada pengolahan lebih lanjut setelah adanya pemanenan. Sedangkan disisi lain jagung dapat dimanfaatkan menjadi banyak aneka olahan pangan yang dapat menambah perekonomian warga desa Tagungguh. Oleh karena itu dengan adanya kegiatan pembuatan Bubur Jagung Tagungguh (Burung Tagungguh) diharapkan dapat diterapkan oleh masyarakat sehingga dapat meningkatkan perekonomian masyarakat desa Tagungguh Kec.Tanjung Bumi Kab. Bangkalan. 
Namun demikian, terdapat beberapa kendala yang dihadapi ketika pengolahan ini, yaitu kondisi jalan yang kurang baik yang mengakibatkan waktu sosialisasi dan pelaksanaan kegiatan sedikit memakan waktu di perjalanan.

\section{Kerajinan dari Biji Jagung}

Tujuan dari kegiatan membuat kerajinan dari biji-bijian jagung dan sejenisnya ini adalah untuk meningkatkan kreatifitas anak-anak di desa Tagungguh. Adapun manfaat yang di dapat adalah meningkatkan nilai ekonomi dari pemanfaatan biji-bijian. Sasaran kegiatan ini adalah anak-anak usia sekolah di Desa Tagungguh. Dalam pembuatan kerajinan tangan ini berasal dari biji-bijian dengan memanfaatkan biji-bijian seperti biji jagung, biji kacang hijau dan beras yang diberi warna. Untuk bahan yang digunakan dalam pembuatan kerjinan ini adalah biji-bijian dan lem kayu yang digunakan untuk menempelkan biji-bijian tersebut ke dalam sebuah gambar yang telah disediakan. Dalam melakukan kegiatan kerajinan berbahan dasar dari biji-bijian ini dilakukan dengan metode demonstrasi secara langsung di depan sasaran anak-anak Desa Tagungguh. Demonstrasi dilakukan melalui peragaan dengan menggunakan media dan alat yang telah disiapkan. Pembuatan kerajinan ini dapat dilakukan dengan cara yang sederhana dan relatif mudah yaitu kulit jagung cukup dijemur dengan panas sinar matahari hingga kering. Setelah kering kulit jagung dapat diwarnai, lalu dikeringkan dan di setrika agar lembarannya dapat terlihat lebih halus dan rata agar mudah dibentuk.

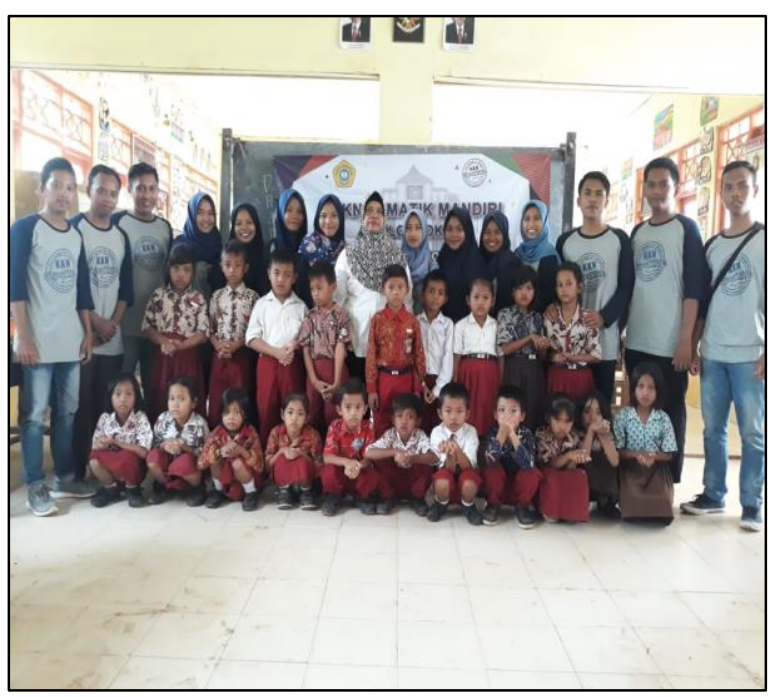

Gambar 2. Kegiatan KKN bersama AnakAnak Desa Tagungguh
Pemasaran produk PJS dan Burung Tagungguh

Kegiatan ini bertujuan untuk mempromosikan produk puding jagung sedot dan bubur jagung. Manfaat nya adalah memberikan referensi produk yang berasal dari jagung kepada warga desa Tagungguh. Adapun Sasaran dari kegiatan ini adalah warga desa Tagungguh. Pada dasarnya pemasaran adalah strategi untuk meningkatkan nilai tambah untuk suatu produk. Di tengah persaingan usaha yang semakin padat, Usaha Kecil Menengah Kreatif harus punya kelebihan dibanding pesaing. Dalam pemasaran produk UMKM harus diketahui keinginan konsumen sehingga kita dapat menghadirkan produk yang diinginkan konsumen. Untuk itu, harus dilakukan evaluasi produk dengan melakukan inovasi untuk mendapatkan produk terbaik. UMKM akan sulit berkembang jika tidak mengetahui cara memasarkan suatu produk. Salah satu hal penting yang diaplikasikan melalui strategi pemasaran adalah strategi promosi.

Kesuksesan suatu UMKM adalah ketika bisa menciptakan produk yang berkualitas serta memasarkan dengan baik. Untuk skala bisnis kecil seperti UMKM tentunya memiliki strategi pemasaran yang berbeda dengan perusahaan besar. UMKM biasanya memiliki budget pemasaran yang terbatas, sehingga diperlukan kreatifitas untuk menemukan cara yang efektif dalam memasarkan produk atau jasa dengan biaya pemasaran yang rendah atau bahkan tidak memerlukan biaya. Strategi iklan, promosi penjualan, penjualan personal, dan hubngan masyarakat (public relations), semuanya digunakan untuk membantu organisasi berkomunikasi dengan konsumennya, menjalin kerjasama antarorganisasi, masyarakat, dan sasaran lainnya. Strategi promosi memainkan peran penting dalam menempatkan posisi produk di mata dan benak pembeli. Promosi memiliki tujuan yaitu memberitahukan, meningkatkan, dan membujuk pembeli serta pihak lain yang berpengaruh dalam proses pembelian.

Bentuk promosi yang paling tradisional adalah iklan. Iklan adalah pemasangan informasi produk di berbagai media dan penerbitan mulai dari Koran, majalah, tabloid, televisi, radio, dan juga internet. Iklan memang efektif menjangkau khalayak yang luas, ettapi dari sisi biaya memang membutuhkan anggaran yang besar. Jika terasa bahwa biaya iklan di media massa cukup besar, bias dicoba bentuk lainnya yaitu dengan brosur, leaflet, dan juga spanduk yang dipasang di sekitar wilayah konsumen berada. 


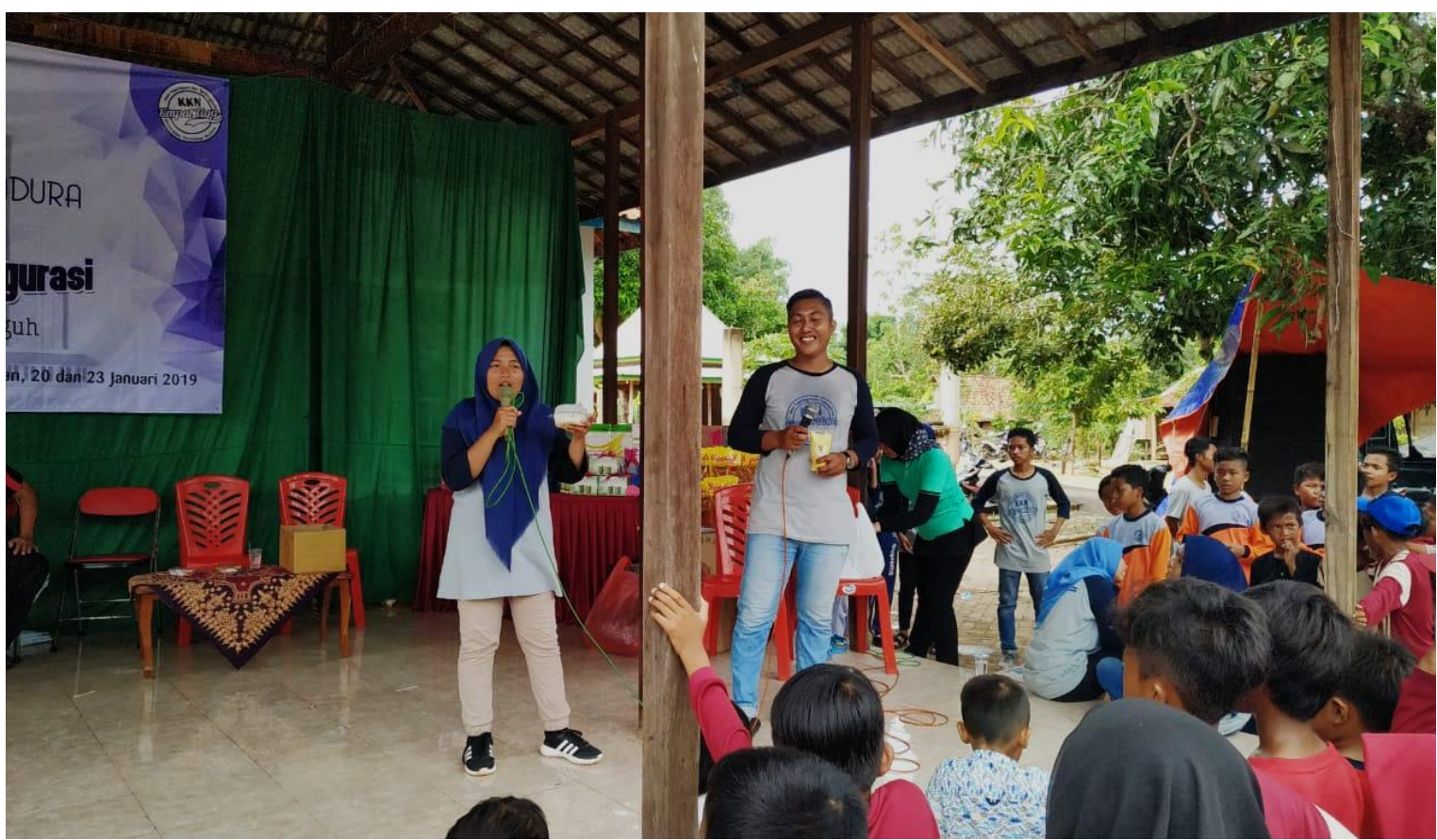

Gambar 3. Mahasiswa KKN Memberikan Penyuluhan kepada Anak-Anak Desa Tagungguh

Cara lain yang efektif adalah melalui promosi dari mulut ke mulut dimana satu orang memberikan penjelasan kepada orang lain karena merasa mendapatkan manfaat yang baik dari produk atau jasa yang digunakan. Promosi ini sangat efektif karena biasanya orang lebih percaya kepada apa yang dikatakan oleh saudara ataupun teman-teman yang sudah merasakan terlebih dahulu.

\section{KESIMPULAN}

Kesimpulan dari kegiatan ini adalah:

1. Pelaksanaan kegiatan diversifikasi komoditas jagung dengan pengelolaan inovatif ini adalah: Pengelolaan Puding Jagung Sedot (PJS), Pengelolaan Bubur Jagung Tagungguh (Burung Tagungguh), Pembuatan Kerajinan dari Biji Jagung, Pemasaran produk PJS dan Burung

2. Kegiatan diversifikasi komoditas jagung memaksimalkan hasil pertanian jagung yang merupakan salah satu komoditas yang unggul di Desa Tagungguh dan diharapkan dapat meningkatkan perekonomian masyarakat sekitar.

3. Kegiatan tersebut mendapatkan respon yang cukup positif dari masyarakat dan pemangku kepentingan dan ke depan bisa diberikan tindak lanjut.

\section{DAFTAR PUSTAKA}

Amzeri, A. 2016. Profil Pengembangan Jagung Madura. Penerbit: UTM Press.

Casson, M. 2012. Entrepreneurship: Teori, Jejaring, Sejarah. Terjemahan. Penerbit: Rajawali Pers.

Efendy, M. 2012. Garam Rakyat: Potensi dan Permasalahan. Penerbit; UTM Press.

Rahayuningsih, E.S. 2016. Profil Ubi Kayu. Penerbit: UTM Press.

Kerja Madura. Penerbit: UTM Press.

Saputro, S.D. 2016. Profil Pendidikan Madura. Penerbit: UTM Press. 
6 Jurnal Pangabdhi 